\title{
TEORI MENGENAI PENCIPTAAN MANUSIA DALAM HADIS NABI; KAJIAN MA'ANIL HADIS
}

\author{
M. Abdul Wahid \\ Universitas Islam Negeri Alauddin Makassar \\ Sulawesi Selatan, Indonesia \\ Email: abduhwahid62@gmail.com
}

\section{Abstrak}

The discourse between religion and science (science) is a classic issue that is still developing in the Western world in the form of secularism. However, Islam does not approach this scientific problem from that perspective because Alquran and Sunnah have provided a complete and perfect system that covers all aspects of human life. This includes the process of human creation. This paper will examine the Hadith Text About the Process of Man's creation and How the Interpretation of the Hadith according to Science. The author found that the Creation of man after the prophet Adam was created through several fertilization phases.

\section{Keywords}

Hadis, Penciptaan Manusia, Nabi Adam

\section{Pendahuluan}

Perseteruan antara agama dan ilmu pengetahuan (sains) merupakan isu klasik yang sampai saat ini masih berkembang di dunia Barat dalam wujud sekularisme. Tetapi, Islam tidak mendekati persoalan sains ini dari perspektif tersebut karena Alquran dan Sunnah telah memberikan sistem yang lengkap dan sempurna yang mencakup semua aspek kehidupan manusia, termasuk kegiatan-kegiatan ilmiah atau penyelidikanpenyelidikan ilmiah. Jadi, kegiatan ilmiah merupakan bagian 
yang integral dari keseluruhan sistem Islam di mana masingmasing bagian memberikan sumbangan terhadap yang lainnya.

Alquran yang dilengkapi dengan penjelas dari Hadis sangat menekankan pentingnya membaca gejala alam dan merenungkannya. Sekedar menyebut contoh mengambil dari kosmologi, fisika, biologi, ilmu kedokteran dan lainnya sebagai tanda kekuasaan Allah untuk dipikirkan oleh manusia. Merenungkan dan menyelidiki dengan kemampuan akal budi serta berusaha memperoleh pengetahuan dan pemahaman alamiah. Kaum muslim zaman klasik memperoleh ilham dan semangat untuk mengadakan penyelidikan ilmiah di bawah sinar petunjuk Alquran. Tulisan ini akan mengkaji Teks Hadis Tentang Proses penciptaan Manusia dan Bagaimana Interpretasi Hadis tersebut dalam Perkembangan Ilmu Pengetahuan.

\section{Hadis Tentang Penciptaan Manusia}

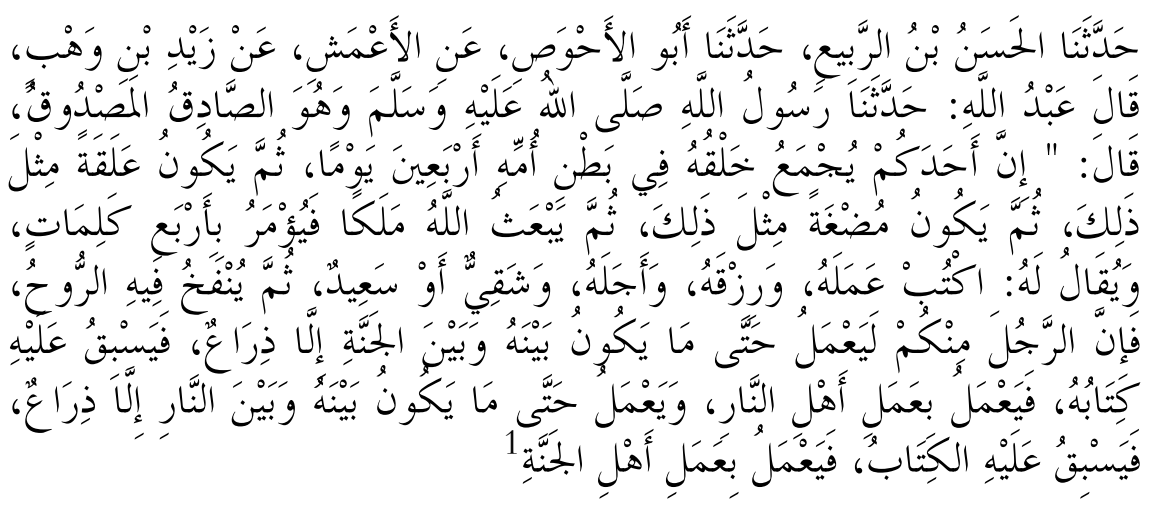

Artinya:

Telah bercerita kepada kami Al Hasan bin ar-Rabi' telah bercerita kepada kami Abu Al Ahwash dari Al A'masy dari Zaid bin Wahb berkata 'Abdullah telah bercerita kepada

${ }^{1}$ Muhammad bin Isma'il Abu 'Abdillah al-Bukhari al-Ju'fi, Sahih alBukhari, Juz IV, (Cet. I; Dar Tauq al-Najah, 1422), h. 122.

TAHDIS Volume 10 Nomor 2 Tahun 2019 
kami Rasulullah shallallahu 'alaihi wasallam, dia adalah orang yang jujur lagi dibenarkan, bersabda: "Sesungguhnya setiap orang dari kalian dikumpulkan dalam penciptaannya ketika berada di dalam perut ibunya selama empat puluh hari, kemudian menjadi 'alaqah (zigot) selama itu pula kemudian menjadi mudlghah (segumpal daging), selama itu pula kemudian Allah mengirim malaikat yang diperintahkan empat ketetapan dan dikatakan kepadanya, tulislah amalnya, rezekinya, ajalnya dan sengsara dan bahagianya lalu ditiupkan ruh kepadanya. Dan sungguh seseorang dari kalian akan ada yang beramal hingga dirinya berada dekat dengan surga kecuali sejengkal saja lalu dia didahului oleh catatan (ketetapan taqdir) hingga dia beramal dengan amalan penghuni neraka dan ada juga seseorang yang beramal hingga dirinya berada dekat dengan neraka kecuali sejengkal saja lalu dia didahului oleh catatan (ketetapan taqdir) hingga dia beramal dengan amalan penghuni surga".

\section{Makna Kosa Kata Pengertian Dosa}

\&-ن?

Kata yujma'u berasal dari asal kata jama'a-yajma'ujam'an adalah fi'il muta'addi (transitif) yang maknanya sama dengan jamma'a dan ajma'a sedangkan bentuk lazim (intransi tif)-nya adalah ijtama'a, tajamma'a dan istajma'a. menurut Ibn Faris, kata yang berakar jim-mim-'ain, menunjukkan pada arti denotative "berkumpulnya sesuatu", sedangkan al-Raghib al-Ashfahani menambahkan, "berkumpulnya sesuatu sehingga berdekatan satu sama lain".

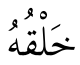




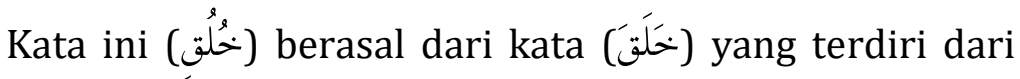
huruf Kha', Lam, dan Qaf, yang memiliki 2 pemaknaan yaitu

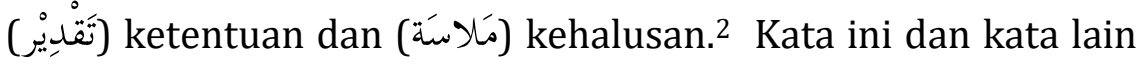
turunannya didalam Alquran disebut 261 kali, tersebar didalam 75 surah. Dari seluruh penyebutan itu sebanyak 11 kali dalam tujuh surah, kata khalaq (خَّلاق)selain menekankan arti penciptaan, juga memiliki makna lain, sekalipun masih berkaitan dengan makna penciptaan, seperti: ikhtilaf (إختلاف)

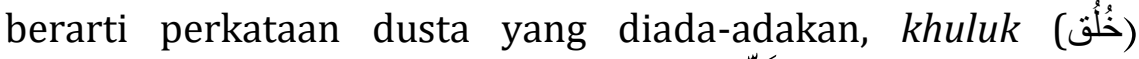
dihubungkan dengan kata awwalin (أَّوَِّين) berarti adat atau kebiasaan dari berbagai pemaknaan di atas.

Kata (نحُلْقِ jika tidak dibarengi dengan adjektivnya, ia selalu berarti budi pekerti yang luhur, tingkah laku, dan watak terpuji. Kata (على) mengandung makna kemantapan. Di sisi lain, ia juga mengesankan bahwa Nabi Muhammad saw. Yang menjadi mitra bicara ayat-ayat di atas berada di atas budi pekerti yang luhur, bukan sekedar berbudi pekerti luhur. Memang, Allah menegur beliau jika bersikap dengan sikap yang hanya baik dan telah biasa dilakukan oleh orang-orang yang dinilai sebagai berakhlak mulia. Rujuklah ke awal surah 'Abasa wa tawalla.

يَوْيًَ

Kata yaum (يوم) adalah bentuk tunggal yang berarti 'hari'.3 Kata yaum (يوم) didalam Alquran sebanyak 375 kali. Kata ini dalam al-Quran kadang-kadang digunakan untuk menerangkan perjalanan waktu mulai dari terbit matahari sampai terbenamnya dan kadang-kadang digunakan untuk menunjukkan zaman, masa, atau priode. Kata yaum (يوم) selalu

${ }^{2} \mathrm{Abu}$ Al-Husain Ahmad bin Faris bin Zakariya, Mu'jam Maqayis AlLugah, Juz VI, (Cet. Dar al-Fikr, thn. 1399 H/ 1979 M), h. 213.

${ }^{3} \mathrm{Abu}$ Al-Husain Ahmad bin Faris bin Zakariya, Mu'jam Maqayis AlLugah, Juz VI, h. 159.

TAHDIS Volume 10 Nomor 2 Tahun 2019 
dirangkaikan dengan kata lain didalam al-Quran Misalnya dirangkaikan dengan kata al-akhir (الآخر) sehingga susunan menjadi al-yaumul akhir (اليوم الآخر) sebagaimana yang dicantumkan dalam ayat ini, yang digunakan untuk menerangkan saat mana tidak ada hari lain setelah hari akhir tersebut. Adapula kata yaum yang dirangkaikan dengan kata alDin (الدين) sehingga menjadi yaumu al-Din (اليوم الدين) yang digunakan untuk menerangkan hari ketika segala amal perbuatan manusia sewaktu hidup didunia diperhitungkan. ${ }^{4}$

عَلَقَة

Kata 'alaqah terambil dari kata yang tersusun atas huruf 'ain, lam dan qaf, yang bermakna dasar menggantungkan sesuatu dengan sesuatu yang lain. ${ }^{5}$ 'alaqah berasal dari kata 'uluq (yang menggantung). 'alaqah terbentuk saat isi kandungan tergantung di tempatnya di dalam rongga rahim.

مُضْغَة

Kata mudhgah terambil dari akar kata yang tersusun atas huruf mim, dha, dan gain yang mempunyai makna dasar mengunyah makanan untuk memakannya. Kata mudhgah dalam penggunaan bahasa sehari-hari sering kali diartikan dengan segumpal daging. Isi kandungan digambarkan seperti itu, demikian pula janin jika bentuknya sudah sempurna.

الله

Kata لله adalah nama tuhan yang paling popular. Para ulama brbrda pendaat menyangkut lafal mulia ini, apakah ia termasuk al-Asma' al-Husna atau tiadak, yang tidak memasukkannya beralasan bahwa al-Asma' al-Husna adalah nama atau sifat Allah. Bukankah yang maha mulia sendiri

4 M. Quraish Shihab. Dkk. Ensiklopedia al-Qur'an, Juz I, (Cet. I; Jakarta: lentera Hati, 2007), h. 113.

${ }^{5}$ Abi al-Husain Ahmad bin Faris bin Zakariyya, Maqayis al-Lugah, Juz I, h. 125. 
menyatakan dalam kitabnya bahwa, (ولله اسماء احسنى) milik Allah nama-nama yang terindah, karena Asma' Husna nama/sifat Allah, maka tentu saja kata "Allah" bukan termasuk di dalamnya. Tetapi ulama lain berpendapat bahwa kata tersebut sedemikian agung, bahkan yang teragung, sehingga tidaklah wajar jika ia tidak termasuk al-Asma' al-Husna.

Menurut mereka yang memasukkan kata ini di dalam alAsma' al-Husna mengatakan, menjadikan lafal Allah sebagian salah satu Asma' al-Husna, bukankah Allah juga merupakan namanya yang indah? Bahkan apabila anda berkata Allah maka apa yang anda ucapkan itu mencakup semua nama-namanya yang lain. Sedangkan bila anda mengucapkan nama-nama yang lain misalnya al-Rahman al-Malik sebagainya maka ia hanya menggambarkan sifat rahmat atau sifat kepemilikannya saja di sisi lain tidak satupun selain yang mahaesaitu yang dapat dinamai Allah, baik secara hakikat aupun majaz, berbeda dengan nama-namanya yang lain, yang secara umum dapat dikatakan bisa disandang oleh mahkluk-mahklukNya. Bukankah kita dapat menamai si Ali yang pengasih sebagai Rahim, atau Ahmad yang berpengetahuan sebagai Alim. ${ }^{6}$ ?

Kata Allah mempunyai kekhusukan yang tidak dimiliki oleh kata selainnya, ia adalah kata yang sempurna hurufhurufnya, sempurna maknanya, serta memiliki kekhusukan berkaitan dengan rahasianya, sehingga sementara ulama menyatakan bahwa kata itulah yang dinamai Ismu-llah al-Azam (nama Allah yang paling mulia) yang bila diucapkan dalam doa' Allah akan mengabulkannya. ${ }^{7}$

Betapapun pendapat itu, yangjelas bahwa kata ini terulang dala Alquran sebanyak 2.698 kali. Secara tegas tuhan yang mahaesa itu sendiri menamai dirinya Allah,

${ }^{6}$ M. Quraish Shihab. Dkk. Ensiklopedia al-Qur'an, Juz I, h.

${ }^{7}$ Quraish Shihab, Tafsir Al-Misbah. Juz II, h.19.

TAHDIS Volume 10 Nomor 2 Tahun 2019 


$$
\text { إنين أنا الله لا إله إلا أنا فاعبدلي وأقم الصلاة لذكري }
$$

Artinya:

Sesungguhnya aku adalah Allah, tiada tuhan selain aku, maka sembahlah aku" (QS. Thaha 20: 14).

$$
\text { رِزْقَهُ }
$$

Kata ini merupakan bentuk fi'l al-Madiy yang berarti memberi rezki, dalam kamus Maqayis al-Lugah diterangkan bahwa kata ini terdiri dari gabungan huruf 3 j yang membentuk makna dasar yang menunjukkan pemberian yang memiliki waktu, kemudian diberikan kepadanya bukan pada waktu yang ditetapkan. ${ }^{8}$ Kata ini semakna dengan kata alHazzudan al-I'ta'u yang sama bermakna pemberian, tetapi semuanya memiliki perbedaan, kata al-Rizq merupakan pemberian yang terus mengalir, al-I'ta'u pemberian yang menghubungkan/bersentuhan langsung dengan yang mengambil, sedangkan kata al-Hazzu adalah pemberian yang sementara/akan terputus atau bias juga di katakan sebagai keberuntungan. ${ }^{9}$

يَعْمَلْ

Sesuatu yang umum dalam setiap pekerjaan yang dikerjakan, ${ }^{10}$ ayat di atas menyebutkan kata 'amal dua kali, sekali dalam bentuk kata kerja lampau (عمل) 'amila/telah mengamalkan untuk menunjukkan telah terlaksananya amal itu, dan yang kedua menggunakan bentuk mashdar/infinitive

${ }^{8} \mathrm{Abu}$ Al-Husain Ahmad bin Faris bin Zakariya, Mu'jam Maqayis AlLugah, Juz II, h. 388.

${ }^{9} \mathrm{Abu}$ al-Hilal al-Hasan bin Abdullah bin Sahl bin Said bin bin Yahya bin Mahranbal-Askariy, al-Furuq al-Lugawiyyah, Juz I (Cet. Al-Qahirah -Misr ; Dar al-Ilm wa al-S|aqafah li al-Nasyr wa al-Tawzi, t.th), hal. 166.

10 Abu al-Husain Ahmad bin Faris bin Zakariya, Juz IV, Mu'jam Maqayis al-Lugah, h. 116. 
noun yaitu dengan kata (عملا) 'amalan. Penggunaan bentuk kata ini mengandung makna kesempurnaan.

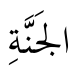

Berasal dari kata جن yang mempunyai satu makna yakni penutup, pelindung bagaikan tabir. ${ }^{11}$ Yaitu tidak dapat dijangkau oleh pancaindra manusia. Dari akar kata inilah pengertiannya berkembang sejalan dengan perkembangan konteks pemakaiannya sehingga terbentuk berbagai kata lain misalnya kata Janin diartikan sebagai bayi yang masih berada dalam kandungan ibunya. Diartikan demikian karena bayi masih tertutup oleh perut ibunya. Salah satu makhluk ciptaan tuhan disebut Jin karena hakikat dan wujudnya tidak dapat diketahui oleh indra manusia. Seseorang yang gila disebut Majnun karena akalnya tertutupi. Kebun yang dipenuhi dengan pohon-pohon sehingga menutupi pandangan manusia dinamai Jannah. Kata ini juga diartikan dengan syurga karena hakikat syurga tertutupI dari pengetahuan indra dan akal manusia atau karena disana terdapat hal-hal yang oleh nabi diketahui sebagai sesuatu yang tidak pernah terlihat oleh mata, terdengar oleh telinga dan terjangkau oleh akal fikiran manusia. ${ }^{12}$

\section{Interkoneksi hadis dengan perkembangan sains modern}

Hadis Ibnu Mas'ud pada riwayat yang lain, beliau bersabda: "jika nuthfah sudah berada selama 43 hari, dalam riwayat lain 42 hari maka Allah utus malaikat untuk menentukan bentuknya." Hingga sabdanya: "Wahai Rabb, lakilaki atau perempuan?" Beliau juga bersabda dalam hadis Hudzaifah bin Usaid: "Malaikat datang kepada nuthfah setelah

${ }^{11} \mathrm{Abi}$ al-Husain Ahmad bin Faris bin Zakariyya, Maqayis al-Lugah, Juz I, hal. 421.

${ }^{12}$ M. Quraish Shihab dkk, Ensiklopedia Al Qur'an, Juz I, h. 386.

TAHDIS Volume 10 Nomor 2 Tahun 2019 
dia tinggal di rahim selama 40 hari atau 45 hari, lalu malaikat berkata: "Wahai Rabb, sengsara atau bahagia?" Dalam riwayat lain: "Bahwa nuthfah berada dalam rahim selama 40 malam, lalu malaikat mendekatinya dan berkata: Wahai Rabb, laki-laki atau perempuan?" dalam riwayat lain: "40 hari lebih sedikit." Dalam hadis Anas: "Sesungguhnya Allah telah mengutus malaikat yang mengurus rahim, lalu dia berkata: "Wahai Rabbnya Nuthfah, wahai Rabbnya 'alaqah, wahai Rabbnya mudghah!" maka ketika dia hendak menyelesaikannya, dia berkata; "Wahai Rabb, laki-laki atau perempuan? Sengsara atau bahagia? Bagaimana rezekinya? Bagaimana ajalnya?"13

Makna hadis ini dalam perkembangan sains adalah terdapat ketiga fase pertama dalam proses penciptaan manusia, yaitu sperma (nuthfah), gumpalan darah ('alaqah), gumpalan daging (mudhgah), berlansung selama empat puluh hari pertama sejak proses pembuahan. Beberapa observasi ilmiah yang dilakukan oleh orang-orang yang bekerja di bidang embriologi terbukti menguatkan sinyalen tersebut. Sperma yang memancar kedalam rahim, lalu Allah pertemukan dalam rahim tersebut selama rentang waktu tersebut (40 hari). Diriwayatkan dari Ibnu Mas'ud bahwa dia menafsirkan kalimat di atas dengan menyatakan, "Nutfah yang memancar kedalam rahim bila Allah menghendaki untuk dijadikan seorang manusia, maka nutfah tersebut mengalir pada seluruh pembuluh darah perempuan sampai kepada kuku dan rambut kepalanya, kemudian tinggal selama 40 hari, lalu berubah menjadi darah yang tinggal di dalam rahim. Itulah yang dimaksud dengan "Allah mengumpulkannya" Setelah 40 hari

13'Iyad bin Musa bin 'Iyad bin 'Amrun, Syarah Sahih Muslim, Juz VIII, (Cet. I; Mesir: Dar al-Wafa' Li al-Taba'ah Wa al-Nasyir Wa al-Tauzi', 1998), h. 123. 
nutfah menjadi 'Alaqah (segumpal darah)."14 Kemudian menjadi Mudhghah (segumpal daging) selama itu juga. ${ }^{15}$

Bentuk gumpalan daging (mudhgah) pada awalnya tidak ada hubungannya sama sekali dengan bentuk manusia. Namun, mudhgah memulai proses menuju bentuk manusia secara bertahap dalam lima hari berikutnya, yaitu fase antara empat puluh hari hingga empat puluh lima hari sejak proses pembuahan.

Pada hari keempat puluh lima, proses pembentukan organ dan kerangka selesai secara nyata, dan proses pembelahan sel dan pengelompokan penciptaan secara terperinci (organ) terus berlangsung setelah itu. Kata nuthfah secara umum berarti air sedikit yang menetes. Dalam disiplin ilmu embriologi, nuthfah berarti tetesan air dari dua sel reproduksi laki-laki dan perempuan. Sedangkan yang dimaksud dalam hadis ini adalah telur yang dibuahi (janin) yang dihasilkan dari pertemuan antara sperma ayah dan ibu, yang disebut dalam Alquran dengan istilah nuthfah berbentuk tumggal (mufrad), namun karena ia bermakna jamak (banyak), maka kata sifat yang menyandinginya pun berbentuk jamak; amsyaj.

1. Perubahan 'alaqah menjadi mudhgah

Nuthfah yang sudah bercampur ini berkembang dengan cara membelah diri dengan cepat menjadi sejumlah sel terkecil, lalu yang terkecil lagi, hingga membentuk gumpalan bulat selsel yang disebut dengan nama morula, empat hari setelah proses pembuahan. Pada hari kelimanya, gumpalan bulat ini

14Taqiyyu al-Din Abu al-Fath Muhammad bin 'Ali bin Wahab bin Muti' al-Qusyairi, Syarah al-Arba'in al-Nawawiyah al-Ahadis al-Sahihah alNabawiyah, Juz I, (Cet. VI; Muassasah al-Riyan, 2003), h. 37.

${ }^{15}$ Isma'il bin Muhammad al-Ansari, al-Tuhfah al-'Arabiyah, Juz I, (Dar al-Ifta Bi al-Mamlukah al-'Arabiyah al-Sa'udiyah, 1417), h. 9. 
membelah dan membentuk apa yang dikenal dengan istilah tembolok atau kantong keturunan (blastocysf).

Pada hari keenam sejak proses pembuahan, sperma yang bercampur, lalu membelah kemudian membentuk kantong ini bergerak-gerak layaknya tembolok dan menanamkan diri di dinding rahim dan sepanjang rahim pada batas $0.5 \mathrm{~cm}$ hingga $0.68 \mathrm{~mm}$, untuk memulai fase penempelan di dinding rahim. Fase ini dikenal dengan istilahfase penanaman (implantation) dan memekan waktu selama seminggu penuh hingga sperma tersebut benar-benar tertanam di dinding rahim. Lalu beralihlah dia dari masa sperma ke mas gumpalan darah.

Pada hari kelima belas dari umur janin, muncullah pita pertama di samping gumpalan darah yang dengan ketertanamannya di dinding rahim, bentuknya pun menjadi sama persis dengan bentuk lintah dan menempuh cara yang sama dengan yang ditempuh lintah dalam memperoleh makanannya. Lintah adalah cacing air yang hidup di kolamkolam, dan menempel pada hewan lain untuk mencari makanan dengan cara menghirup darah hewan tersebut. Hal inilah yang dilakukan janin selama fase gumpalan darah ('alaqah), seiring dengan menempelnya sperma yang telah bercampur (yang dikenal dengan nama kantong keturunan) pada dinding rahim ibunya. Proses tersebut berlangsung dari hari keenam hingga hari keempat belas, yaitu fase penanaman (yang disebut dalam Alquran dengan istilah harts atau impalantation dalam istilah medis), hingga ia benar-benar tertanam di dinding rahim. Setelah itu, ia pun mulai menyerap makanan melalui darah ibu seperti lintah yang menyerap 
makanan dari darah hewan yang ditempelinya atau diindukinya. ${ }^{16}$

Proses ini berlangsung hampir seminggu hingga ia benar-benar menempel erat secara sempurna pada dinidng rahim ibu, dan menyerupai bentuk plasenta embrionik yang menempel dengan perantara ikatan penghubung yang kelak akan menjadi tali pusar (umbilical cord). Usia janin kala itu hamper dua minggu, dan panjang gumpalan darah berkisar antara $1.5 \mathrm{~mm}$ sampai $3 \mathrm{~mm}$. Proses pertumbuhan tali punggung (dorsal cord) memakan waktu kra-kira sepuluh hari (sejak hari keenam setelah pembuahan hingga hari keenam belas). Janin menunjukkan bentuknya sebagai gumpalan darah secara sempurna pada minggu ketiga sejak pembuahan (hari kelima belas hingga kedua puluh lima). Pada fase ini gumpalan darah sudah mulai menampakkan tunas saraf yang lembut, dan mulai menampakkan tempat tumbuh rambut.

Penggunaan kata sambung "kemudian" (tsumma) dalam hadis Nabi saw., di atas menunjukkan selesainya tenggat waktu masing-masing fase nuthfah (sperma) dan 'alaqah (gumpalan darah). Janin mencapai akhir fase 'alaqah sekitar hari kedua puluh empat hingga hari kedua puluh lima sejak awal pembuahan.

2. Perubahan mudhgah ke tulang

Dua hari setelah itu (hari kedua puluh enam sejak pembuahan) ${ }^{17}$ 'alaqah berubah menjadi mudhgah (segumpal daging). Fase ini ditandai dengan mulai tampaknya bagianbagian tubuh atau kelompok-kelompok anggota tubuh, kemudian bertambah menjadi lebih kurang 40 hingga 45

16Zaghlul An-Najjar, Sains Dalam Hadis, (Cet. I; Jakarta: Amzah, 2011), h. 411.

17 Zaghlul An-Najjar, Pembuktian Sains Dalam Sunnah, (Cet. I; Jakarta: Amzah, 2007), h. 248.

TAHDIS Volume 10 Nomor 2 Tahun 2019 
anggota tubuh. Semua proses ini berlangsung mulai akhir minggu keempat hingga awal minggu ketujuh sejak proses pembuahan (dari hari kedua puluh enam hingga hari keempat puluh dua umur janin). Bagian-bagian tubuh ini adalah bagian tubuh yang oleh fase ini diberi bentuk mudhgah (kata mudhgah pada awalnya bermakna sepotong kecil daging yang dikunyah gigi). Fase mudhgah terus berlangsung sampai mendekati minggu keenam dari kehamilan, dan fase ini berakhir pada sentimeter pertama dari panjang janin (sekitar $3.2 \mathrm{~mm}$ sampai $13 \mathrm{~mm})$.

Bersamaan dengan permulaan minggu ketujuh dari kehamilann (hari keempat puluh tiga hingga hari keempat puluh Sembilan usia janin) dimulailah fase pembemtukan tulang dengan dimulainya penyebaran kerangka pada janin. Proses ini berlangsung dengan cara pengerasan tulang rawan secara bertahap di sekitar tempat tumbuhnya anggota tubuh dan selesai fase mudhgah. Dan bersamaan denga terbentuknya tulang, janin yang telah memiliki pangjang antara 14 mm-20 mm ini pun mulai menunjukkan perawakan badannya, dan menampakkan ujjung-ujung jari, dan kantong otak.

3. Pembungkusan Tulang Dengan Daging

Seiring dengan permualaan minggu ketujuh dimulailah fase pembentukan otot dan pembungkusan tulang dengan daging. Dan pada waktu ini panjang janin sudah mencapai 2.3 $\mathrm{cm}$ (22 mm sampai $31 \mathrm{~mm}$ ). setelah itu, dimulailah fase pertumbuhan akhirm dari awal minggu ketiga puluh delapan dari kehidupan janin. Selama fase ini cirri-ciri kemanusiaan mulai tampak secara bertahap. Pembungkusan tulang dengan otot dan juga penutupan otot dengan daging pun telah selesai. ${ }^{18}$ Dan mualailah tampak bentuk masing-masing anggota tubuh

${ }^{18}$ Nadiyah Tayyarah, Sains Dalam al-Qur'an, (Cet. IV; Jakarta: Zaman, 2014), h. 218. 
secara jelas. Proses pertumbuhan organ-organ tubuh ini ratarata berjalan lambat hingga mencapai awal minggu kedua belas. Ketika itulah proses pertumbuhan mulai berjalan cepat sampai hari kelahiran. Maka Maha sucilah Allah, pencipta yang paling baik.

Makna hadis Rasulullah saw., disampaikan kepada umatnya bahwa ketiga fase dar nuthfah hingga mudhgah berlangsung sekitar enam minggu atau empat puluh hari. Sinyalemen hadis ini dipertegas dan dikuatkan oleh hasil penelitian mutakhir dalam disiplin ilmu embriologi.

Namun, ada sebagian kalangan ulama hadis yang memahami masa itu sebagai tiga kali lipatnya (yaitu 120 hari). Karena mereka memahami frasa mitsl dzalika dalam konteks hadis di atas sebagai isyarat pada rentang waktu empat puluh hari pada setiap fase dari ketiga fase yang ada, yaitu nuthfah, 'alaqah, dan mudhgah. Pemahaman ini menafikkan hadis Nabi saw., yang lain: ketika sperma telah berumur empat puluh dua hari malam, maka Allah mengutus malaikat untuk memberinya bentuk. Mereka menciptakan pendengarannya, penglihatannya, kulitnya, dagingnya, dan tulang-tulangnya. (HR. Abu Dawud dan al-Thabari). ${ }^{19}$

Telah dibuktikan dalam beberapa studi dalam bidang embriologi bahwa proses pembentukan organ tubuh ini dimulai sejak akhir fase mudhgah, yaitu pada akhir minggu keenam sejak kehamilan (atau setelah empat puluh dua malam). Dengan demikian, terbuktilah kebenaran sabda RAsulullah saw., dalam hadis yang telah disebutkan di atas, dan dalam segala hadis yang disabdakan.

Tampaknya, penyebab kesamaran masalah ini bagi sebagian pensyarah hadis generasi pertama adalah karena 
tidak disebutkan frasa fi dzalika sebelum kata 'alaqah dan mudhgah pada sebagia periwayatan hadis, misalnya hadis versi al-Bukhari. Sementara versi yang lebih lengkap (dengan tambahan fi dzalika) diriwayatkan oleh Imam Muslim, sehingga semakin menegaskan bahwa makana frasa mits dzalika dalam riwayat 'Abdullah bin Mas'ud ra., tidak mungkin menunjukkan kesamman waktu, empat puluh hari bagi masing-masing fase, melainkan menunjukka kesamaan dalam penghimpunan penciptaan.

4. Penjelasan ditiupnya ruh

Para ulama bersepakat bahwa ruh ditiupkan ke dalam janin setelah janin berumur seratus dua puluh hari terhitung dari mulai terjadinya pembuahan. Yaitu ketika usia kehamilan sudah empat bulan dan memasuki bulan yang kelima. ${ }^{20}$

Semua itu benar berdasarkan kenyataan yang dapat disaksikan, maka semenjak itu ditetapkan hukum-hukum untuk memenuhi kebutuhannya seperti hukum tentang penyandaran nasabnya dan kewajiban pemberian nafkah. Dan hal itu diyakinkan dengan bergeraknya janin dalam rahim. Inilah hikmah mengapa istri yang ditinggal mati suaminya, masa iddahnya selama empat bulan sepuluh hari. Alasannya ialah untuk meyakinkan bahwa rahimnya benar-benar kosong dari janin tanpa ada sedikit pun tanda-tanda kehamilan. Ruh, yang membuat manusia hidup, adalah urusan Allah sebagaimana firman-Nya.

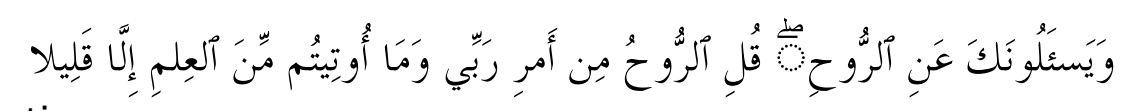
Artinya:

${ }^{20} \mathrm{Abu}$ Muhammad Muhammad bin Ahmad bin Musa bin Ahmad bin Husain, 'Umdah al-Qari Syarah Sahih al-Bukhari, Juz III, (Bairut: Dar Ihya' alTuras al-'Arabi, t. th), h. 295. 
Dan mereka bertanya kepadamu tentang roh. Katakanlah: "Roh itu termasuk urusan Tuhan-ku, dan tidaklah kamu diberi pengetahuan melainkan sedikit"

Dalam syarah Muslim karangan Imam Nawawi disebutkan bahwa ruh adalah jasad halus yang mengalir dalam badan dan merambat di dalamnya sebagaimana merambatnya air didalam batang pohon yang hidup. Dalam kitab Ihya Ulumuddin Imam Al-Ghazali berkata, "ruh adalah unsur yang berdiri sendiri yang bekerja di dalam badan."

\section{Penutup}

Penciptaan manusia setelah nabi Adam diciptakan melalui beberapa fase, fertilisasi atau pembuahan adalah peleburan antara inti sel telur dengan inti sel sperma. Dari ratusan juta sperma hanya satu yang berhasil membuahi sel telur. Fertilisasi berlangsung di saluran telur, saat fertilisasi kepala sperma menembus dinding sel telur sedangkan ekornya tertinggal di luar. Selanjutnya inti telur dan inti sperma bersatu setelah bersatu ovum menjadi zygote.

Perkembangan janin dibagi dalam tiga tahapan besar. Pertama adalah perkembangan pada triwulan I, mulai dari zygote terbentuk sampai janin berusia tiga bulan, perkembangan terpusat pada perkembangan fungsi-fungsi organ, seperti otak, jantung, paru-paru. Pada triwulan II (bulan empat, lima dan enam) pertumbuhan terpusat pada anggota tubuh yaitu kaki, tangan, jari-jari, pada triwulan III, dapat dikatakan bahwa pembentukan sebagian organ telah lengkap. 


\section{DAFTAR PUSTAKA}

'Amrun, 'Iyad bin Musa bin 'Iyad. Syarah Sahih Muslim. Juz VIII. Cet. Ke-I. Mesir: Dar al-Wafa' Li al-Taba'ah Wa al-Nasyir Wa al-Tauzi'. 1998

al-Ansari, Isma'il bin Muhammad. al-Tuhfah al-'Arabiyah. Juz I. Dar al-Ifta Bi al-Mamlukah al-'Arabiyah al-Sa'udiyah. $1417 \mathrm{H}$.

al-Ju'fi, Muhammad bin Isma'il Abu 'Abdillah al-Bukhari. Sahih al-Bukhari. Juz IV. Cet. Ke-I. Dar Tauq al-Najah. 1422.

al-Qusyairi, Taqiyyu al-Din Abu al-Fath Muhammad bin 'Ali bin Wahab bin Muti'. Syarah al-Arba'in al-Nawawiyah alAhadis al-Sahihah al-Nabawiyah. Juz I. Cet. Ke-VI. Muassasah al-Riyan. 2003.

An-Najjar, Zaghlul. Pembuktian Sains Dalam Sunnah. Cet. Ke-I. Jakarta: Amzah. 2007.

An-Najjar, Zaghlul. Sains Dalam Hadis. Cet. Ke-I. Jakarta. Amzah. 2011.

Askariy, Abu al-Hilal al-Hasan bin Abdullah bin Sahl bin Said bin bin Yahya bin Mahranbal- al-Furuq. al-Lugawiyyah. Juz I. Al-Qahirah -Mesir. Dar al-Ilm wa al-S|aqafah li alNasyr wa al-Tawzi.

Husain, Abu Muhammad Muhammad bin Ahmad bin Musa bin Ahmad. 'Umdah al-Qari Syarah Sahih al-Bukhari. Juz III. Bairut. Dar Ihya' al-Turas al-'Arabi.

Quraish Shihab, Tafsir Al-Misbah. Juz II, h.19.

Shihab, M. Quraish Dkk. Ensiklopedia Alquran. Juz I. Cet. Ke-I. Jakarta: lentera Hati. 2007.

Tayyarah, Nadiyah. Sains Dalam Alquran. Cet. Ke-IV. Jakarta. Zaman. 2014.

Zakariya, Abu Al-Husain Ahmad bin Faris. Mu'jam Maqayis AlLugah. Juz VI. Cet. Ke-I. Dar al-Fikr. 1979. 